\title{
Nanoparticulate Metal Complexes Prepared With Compressed Carbon Dioxide: Correlation of Particle Morphology With Precursor Structure
}

\author{
Supporting Information
}

Chad Johnson, Sarika Sharma ${ }^{\dagger}$, Bala Subramaniam, and A. S. Borovik ${ }^{\dagger}$

Department of Chemical and Petroleum Engineering

Center for Environmentally Beneficial Catalysis

University of Kansas

Lawrence, KS 66045

'Department of Chemistry

Center for Environmentally Beneficial Catalysis

University of Kansas

Lawrence, KS 66045 


\section{General Methods}

All reagents were purchased from commercial sources and used as received, unless otherwise noted. Syntheses of some complexes were conducted in a Vacuum Atmospheres Dry box under an argon atmosphere. Standard Schlenk techniques were used during the work-up of some reactions and manipulations of samples outside the drybox.

\section{Preparative Methods}

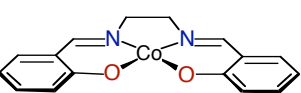

Co(salen) This material was purchased from Aldrich (23,606-3).

EPR: (X-band, solid, 77K) g $=2.00 . \lambda_{\max } / \mathrm{nm}$ : (phosphate buffer

solution (aq), suspension) 250, 376. ELEMENTAL ANALYSIS: Theoretical

(\%) C 59.09, H 4.34, N 8.61, Co 18.12. Experimental (\%) C 57.08, H 4.25, N 8.25, Co 17.02.

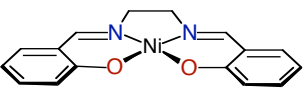

Ni(Salen) To a $500 \mathrm{~mL}$ round bottom flask was added $2.2196 \mathrm{~g}(8.2822$ mmol) of salen (N,N'-disalicylideneethylenediamine) that was partially dissolved in $200 \mathrm{~mL}$ of a 1:1 solution of THF and water to give a yellow suspension. To this mixture was added 2 equivalents of $\mathrm{K}_{2} \mathrm{CO}_{3}(2.2297 \mathrm{~g}, 16.133$ mmol) and 1 equivalent of $\mathrm{Ni}^{\mathrm{II}}(\mathrm{OAc})_{2} \cdot 4 \mathrm{H}_{2} \mathrm{O}(2.0516 \mathrm{~g}, 8.2440 \mathrm{mmol})$ simultaneously. The reaction was stirred for $18 \mathrm{~h}$ at room temperature and pressure as the solution color changed from yellow to dark orange. The solid product was filtered using a $60 \mathrm{~mL}$ fine frit and washed with diethyl ether and then water until the filtrate became clear. The solid was dried under vacuum overnight. The yield of the complex was $2.4108 \mathrm{~g}(90 \%)$. ${ }^{1} \mathrm{H}$ NMR: $\left(\mathrm{CDCl}_{3}, \mathrm{ppm}\right) \delta=3.44$ (s, $\left.4 \mathrm{H}, \mathrm{CH}_{2} \mathrm{CH}_{2}\right) ; 6.52-6.56$ (m, 2H, salicyl phenyl); $7.03-7.05$ (d, 2H, salicyl phenyl); 7.06 7.09 (dd, 2H, salicyl phenyl); $7.19-7.62(\mathrm{~m}, 2 \mathrm{H}$, salicyl phenyl); 7.51 (s, 2H, -NCH(Ph)). $\lambda_{\max } / \mathrm{nm}$ : (DMSO) $\left(\varepsilon, \mathrm{M}^{-1} \mathrm{~cm}^{-1}\right) 390$ (4233), 408 (6573), 440 (3390), $540(121)^{1}$; (suspension in phosphate buffer solution) 250, 323, 389. IR: $\left(\mathrm{KBr}, \mathrm{cm}^{-1}\right) 469(\mathrm{Ni}-\mathrm{N}), 411(\mathrm{Ni}-\mathrm{O})^{2}$. ELEMENTAL ANALYSIS: Theoretical (\%) C 59.13, H 4.34, N 8.62, Ni 18.06. Experimental (\%) C 58.93, H 4.35, N 8.44, Ni 17.12.

$\mathbf{R u}(\mathbf{N O}) \mathbf{C l}_{3}$ This compound was synthesized following a similar procedure described by KochMitchell. ${ }^{3} \mathrm{RuCl}_{3} \cdot \mathrm{xH}_{2} \mathrm{O}(3.028 \mathrm{~g})$ was dissolved in $75 \mathrm{~mL}$ of $1 \mathrm{M} \mathrm{HCl}$ and the solution was degassed with nitrogen for 10 minutes. The mixture was brought to reflux and an aqueous solution $(35 \mathrm{~mL})$ of $\mathrm{NaNO}_{2}(3.0171 \mathrm{~g}, 43.726 \mathrm{mmol})$ was added dropwise. After $4 \mathrm{~h}$ of reflux, the solution was cooled to room temperature and the solvent was removed under reduced pressure. The red/brown residue was dissolved in $35 \mathrm{~mL}$ of ethanol and filtered to remove excess salts. The filtrate was washed using $6 \mathrm{M} \mathrm{HCl}$ and then $25 \mathrm{~mL}$ of water with the solvent being removed after each wash under reduced pressure. This final water washing was repeated three times. The final salt was dried in a vacuum oven at $60{ }^{\circ} \mathrm{C}$ to yield $3.275 \mathrm{~g}(95 \%)$ of a red brown solid. IR: (Nujol, $\left.\mathrm{cm}^{-1}\right) 1898$ (NO). ${ }^{3}$

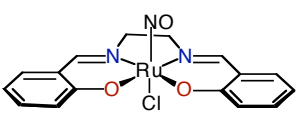

$\mathbf{R u}(\mathbf{s a l e n})(\mathbf{N O})(\mathbf{C l})$ This complex was synthesized following a similar procedure described by Koch-Mitchell. ${ }^{3}$ Under an argon atmosphere, a $50 \mathrm{~mL}$ DMF solution of salen $(1.0034 \mathrm{~g}, 3.7441 \mathrm{mmol})$ was treated with 2 equivalents of solid $\mathrm{KH}(0.300 \mathrm{~g}, 7.48 \mathrm{mmol})$. After $\mathrm{H}_{2}$ evolution was completed ( $\left.30 \mathrm{~min}\right)$, $\mathrm{Ru}(\mathrm{NO}) \mathrm{Cl}_{3}(0.890 \mathrm{~g}, 3.75 \mathrm{mmol})$ was added. This reaction mixture was taken out of the dry box 
and was refluxed for $2 \mathrm{~h}$ under $\mathrm{N}_{2}$. The DMF was removed under reduced pressure and the solid residue was allowed to cool overnight. The brown solid was further purified using silica gel flash chromatography with a mobile phase of $2 \%$ methanol/98\% $\mathrm{CH}_{2} \mathrm{Cl}_{2}$. Fractions containing $\mathrm{Ru}$ (salen)(NO)(Cl) were combined and the solvent was removed under reduced pressure to yield $0.724 \mathrm{~g}(60 \%)$ of a brown solid. ${ }^{1} \mathrm{H}$ NMR: $\left(\mathrm{CDCl}_{3}, \mathrm{ppm}\right) \delta=3.97-4.02$ and $4.36-4.41(\mathrm{dd}, 4 \mathrm{H}$, $\mathrm{CH}_{2} \mathrm{CH}_{2}$ ); 6.68 - 6.71 (t, 2H, salicyl phenyl); $7.24-7.26$ (d, 2H, salicyl phenyl); 7.30 - 7.32 (d, $2 \mathrm{H}$, salicyl phenyl); $7.41-7.45$ (t, 2H, salicyl phenyl); $8.26(\mathrm{~s}, 2 \mathrm{H},-\mathrm{NCH}(\mathrm{Ph}))^{4}$. IR: $\left(\mathrm{KBr}, \mathrm{cm}^{-1}\right)$ $1832(\mathrm{NO}), 1603(\mathrm{C}=\mathrm{N}), 1520(\mathrm{C}=\mathrm{C})^{4} \cdot \lambda_{\max } / \mathrm{nm}$ : $\left(\mathrm{CH}_{2} \mathrm{Cl}_{2}\right) 378^{4}$; (suspension in phosphate buffer solution, nm) 249, 271 (sh), 383.

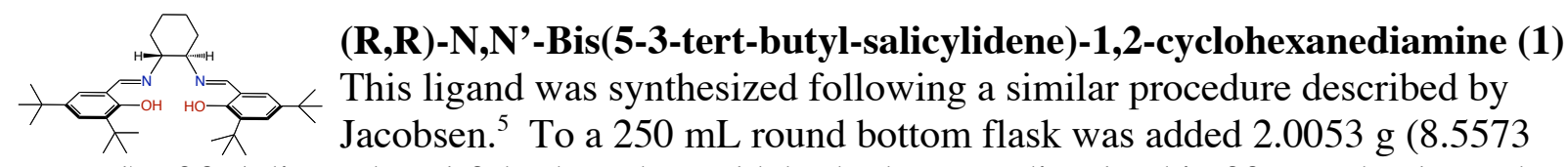
mmol) of 3,5 di-tert butyl-2-hydroxybenzaldehyde that was dissolved in $20 \mathrm{~mL}$ absolute ethanol. Concurrently, (R,R)-1,2-diammoniumcyclohexane mono-(+)-tartrate salt ${ }^{6}(1.1219 \mathrm{~g}, 4.2451$ mmol) was dissolved in a basic $(\mathrm{NaOH}) 0.2 \mathrm{M}$ aqueous/absolute ethanol solution $(1: 2)$. This salt solution was added dropwise to the benzaldehyde solution and the mixture was refluxed under nitrogen for $1 \mathrm{~h}$. The reaction mixture was filtered using a $60 \mathrm{~mL}$ medium frit and washed with 95\% ethanol. The product was then extracted into methylene chloride. The frit was washed with additional methylene chloride until the solid was colorless. The solvent was removed under reduced pressure to yield $1.6843 \mathrm{gm}(70 \%)$ of a yellow solid. ${ }^{1} \mathrm{H}$ NMR: $\left(\mathrm{CDCl}_{3}, \mathrm{ppm}\right) \delta=1.24$ $(\mathrm{s}, 9 \mathrm{H}) ; 1.41(\mathrm{~s}, 9 \mathrm{H}) ; 1.45(\mathrm{~m}, 1 \mathrm{H}) ; 1.65-1.8(\mathrm{~m}, 1 \mathrm{H}) ; 1.8-2.0(\mathrm{~m}, 2 \mathrm{H}) ; 3.32(\mathrm{~m}, 1 \mathrm{H}) ; 6.98(\mathrm{~d}$, $1 \mathrm{H}) ; 7.30(\mathrm{~d}, 1 \mathrm{H}) ; 8.30(\mathrm{~s}, 1 \mathrm{H}) ; 13.72(\mathrm{~s}, 1 \mathrm{H}) .^{5}$

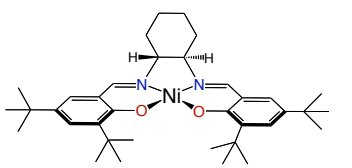

Ni(salen*) To a $250 \mathrm{~mL}$ round bottom flask was added $1.0087 \mathrm{~g}$ (1.8446 mmol) of (1) that was dissolved in $44 \mathrm{~mL}$ of methylene chloride.

Concurrently, $\mathrm{Ni}^{\mathrm{II}}(\mathrm{OAc})_{2} \cdot 4 \mathrm{H}_{2} \mathrm{O}(0.5076 \mathrm{~g}, 2.040 \mathrm{mmol})$ was dissolved in $25 \mathrm{~mL}$ of dry methanol. The nickel solution was added dropwise to the reaction mixture was stirred for $2 \mathrm{~h}$ at room temperature. The mixture was then cooled to $3^{\circ} \mathrm{C}$ in an ice bath and stirred for an additional $0.5 \mathrm{~h}$. The solid product was filtered using a $60 \mathrm{~mL}$ medium frit and washed with cold dry methanol until the filtrate became clear. The solid was dried under vacuum overnight. The yield of the complex was $0.7316 \mathrm{~g}(66 \%)$. ${ }^{1} \mathrm{H} \mathrm{NMR}:\left(\mathrm{CDCl}_{3}, \mathrm{ppm}\right) \delta=$ $1.28(\mathrm{~s}, 9 \mathrm{H}) ; 1.34(\mathrm{~m}, 2 \mathrm{H}) ; 1.43(\mathrm{~s}, 9 \mathrm{H}) ; 1.92(\mathrm{~m}, 1 \mathrm{H}) ; 2.45(\mathrm{~m}, 1 \mathrm{H}) ; 2.99(\mathrm{~m}, 1 \mathrm{H}) ; 6.90(\mathrm{~d}, \mathrm{~J}=$ $2.4 \mathrm{~Hz}, 1 \mathrm{H}) ; 7.31(\mathrm{~d}, 1 \mathrm{H}) ; 7.40(\mathrm{~s}, 1 \mathrm{H})$. ELEMENTAL ANALYSIS: Theoretical (\%) $\mathrm{C} 71.41, \mathrm{H}$ 8.99, N 4.63, Ni 9.69. Experimental (\%) C 71.72, H 8.66, N 4.57, Ni 9.55.

\section{Experimental Procedure}

The experimental set-up used for the PCA runs is described previously ${ }^{7,8}$. The procedure is identical for the different complexes with variations in processing conditions as shown in Table $\mathrm{S} 1$. Carbon dioxide, flowing in parallel from two dip-tube cylinders, is dried in a silica gel column and compressed to the operating pressure by a pneumatically operated gas booster. After passing through a surge tank immersed in a temperature-controlled water bath, where pressure fluctuations are dampened, it enters the precipitation chamber through the converging diverging annulus of a co-axial nozzle located inside the narrow $2.5 \mathrm{~L}$ precipitator vessel. The solvent 
(methylene chloride), containing dissolved complex, is supplied at a constant flow rate by a syringe pump (Isco 314) and fed through the inner capillary of the nozzle $(152.4 \mu \mathrm{m})$ into the temperature controlled precipitation chamber. The co-axial $\mathrm{CO}_{2}$-stream in the convergingdiverging nozzle rapidly disperses the liquid jet and precipitation takes places at the exit of the nozzle. A stainless steel insert was fabricated to decrease dead volume in the precipitation chamber and directs the flow towards the outlet. The particles are collected outside of the reactor on a filter unit $(0.2 \mu \mathrm{m})$, also maintained at constant temperature by being immersed in the same water bath as the chamber. The $\mathrm{CO}_{2}$-solvent mixture is depressurized across a heated backpressure regulator and the solvent recovered in a glass cyclone. Following the cessation of spraying the organic solvent, additional $\mathrm{CO}_{2}$ was sent through the system to ensure the removal of residual solvent from the processed particles. The system was then depressurized to atmospheric pressure and the particles were harvested.

Table S1: Typical Processing Conditions

\begin{tabular}{|c|c|c|c|c|c|}
\hline & Chamber & Chamber & Solution & Solution & $\mathrm{CO}_{2}$ \\
\cline { 2 - 6 } & Pressure & Temperature & Concentration & Flow Rate & Flow Rate \\
\cline { 2 - 6 } System & $( \pm 0.3$ bar $)$ & $\left( \pm 0.5^{\circ} \mathrm{C}\right)$ & $(\mathrm{mg} / \mathrm{mL})$ & $(\mathrm{g} / \mathrm{min})$ & $(\mathrm{g} / \mathrm{min})$ \\
\hline $\mathrm{Ni}^{\prime \prime}($ salen$)$ & 85 & 40 & 10 & 1.93 & 108.4 \\
\hline $\mathrm{Co}^{\prime \prime}($ salen$)$ & 80 & 37 & 5.3 & 1.93 & 108.4 \\
\hline $\mathrm{Ru}($ salen)(NO)(Cl) & 81 & 38 & 5.1 & 1.93 & 108.4 \\
\hline $\mathrm{Ni}^{\prime \prime}\left(\right.$ salen$\left.{ }^{*}\right)$ & 81 & 37 & 9.9 & 1.93 & 108.4 \\
\hline
\end{tabular}

\section{Additional SEM Images}
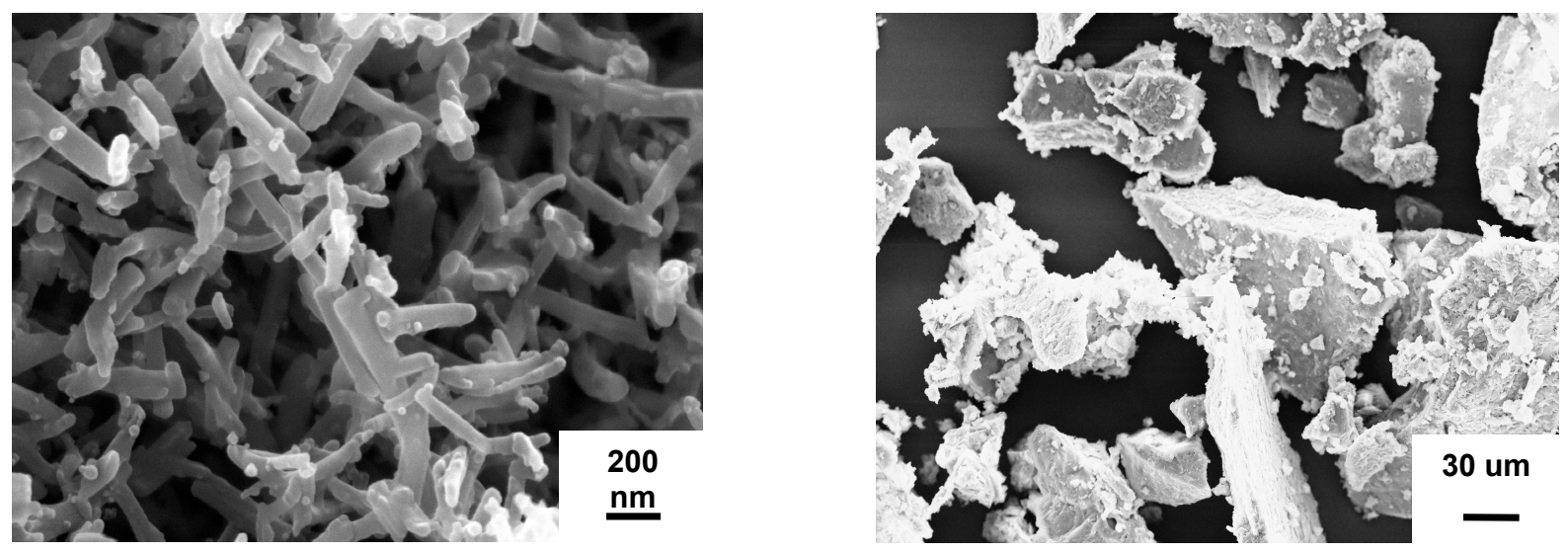

Figure S1 and S2: SEM Images of processed [Co ${ }^{\mathrm{II}}$ (salen)] (left) and unprocessed $[\mathrm{Ru}($ salen $)(\mathrm{NO})(\mathrm{Cl})]$ (right) 


\section{Analysis of Processed Material}

\section{Co(salen)}

The complex was processed using the PCA technique and then compared to starting precursor material. EPR: (X-band, solid, 77K) $\mathrm{g}=2.00$. $\lambda_{\max } / \mathrm{nm}$ : (suspension in phosphate buffer solution) 250, 374. ELEMENTAL ANALYSIS: Theoretical (\%) C 59.09, H 4.34, N 8.61, Co 18.12. Experimental (\%) C 56.92, H 4.13, N 8.11, Co 16.66.

\section{Ni(salen)}

The complex was processed using the PCA technique and then compared to starting precursor material. $\lambda_{\max } / \mathrm{nm}$ : (suspension in phosphate buffer solution) $250,323,389$. ELEMENTAL ANALYSIS: Theoretical (\%) C 59.13, H 4.34, N 8.62, Ni 18.06. Experimental (\%) C 58.76, H 4.25, N 8.42, Ni 17.65.

\section{$\operatorname{Ru}($ salen $)(\mathrm{NO})(\mathrm{Cl})$}

The complex was processed using the PCA technique and then compared to starting precursor material. This material is diamagnetic so the EPR signal should be silent as shown in Figure S6. $\lambda_{\text {max }} / \mathrm{nm}$ : (suspension in phosphate buffer solution) 240, $265(\mathrm{sh}), 361$. IR: $\left(\mathrm{KBr}, \mathrm{cm}^{-1}\right) 1833$ (NO), $1602(\mathrm{C}=\mathrm{N}), 1529(\mathrm{C}=\mathrm{C})$.

\section{Ni(salen*)}

The complex was processed using the PCA technique and then compared to starting precursor material. ELEMENTAL ANALYSIS: Theoretical (\%) C 71.41, H 8.99, N 4.63, Ni 9.69. Experimental (\%) C 71.73, H 8.70, N 4.62, Ni 9.05.

The following figures graphically display the similarities between the unprocessed and processed material. 


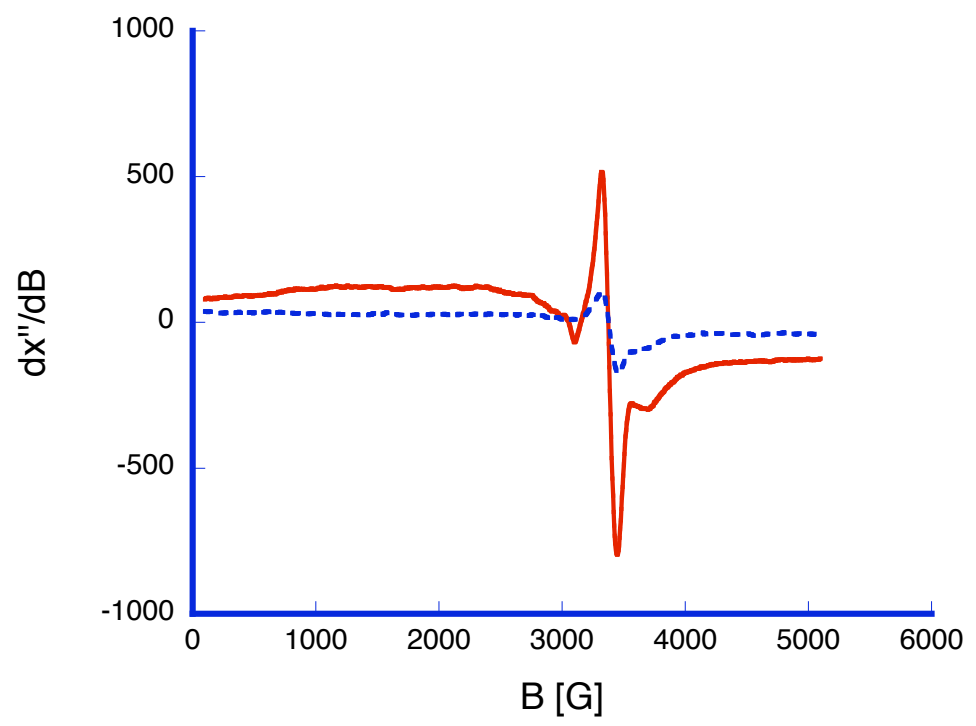

Figure S3: X-band EPR spectra measured at 77K for solid samples of processed (---) and unprocessed (-) $\mathrm{Co}^{\mathrm{II}}$ (salen)

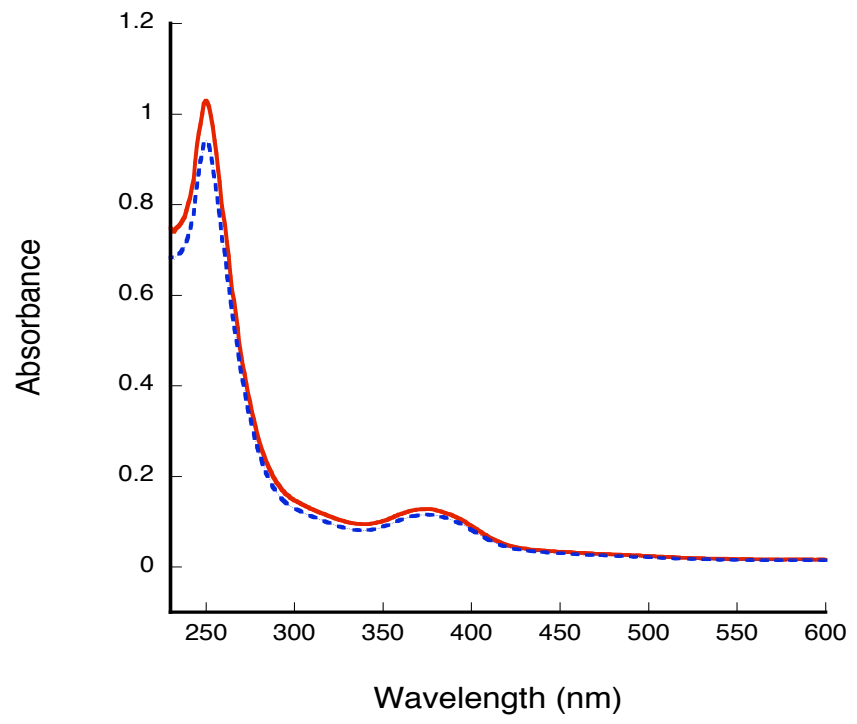

Figure S4: Electronic absorption spectra of processed (---) and unprocessed (-) Co ${ }^{\text {II }}($ salen) suspended in phosphate buffer solution $(0.05 \mathrm{M}, \mathrm{pH}=7.2)$ 


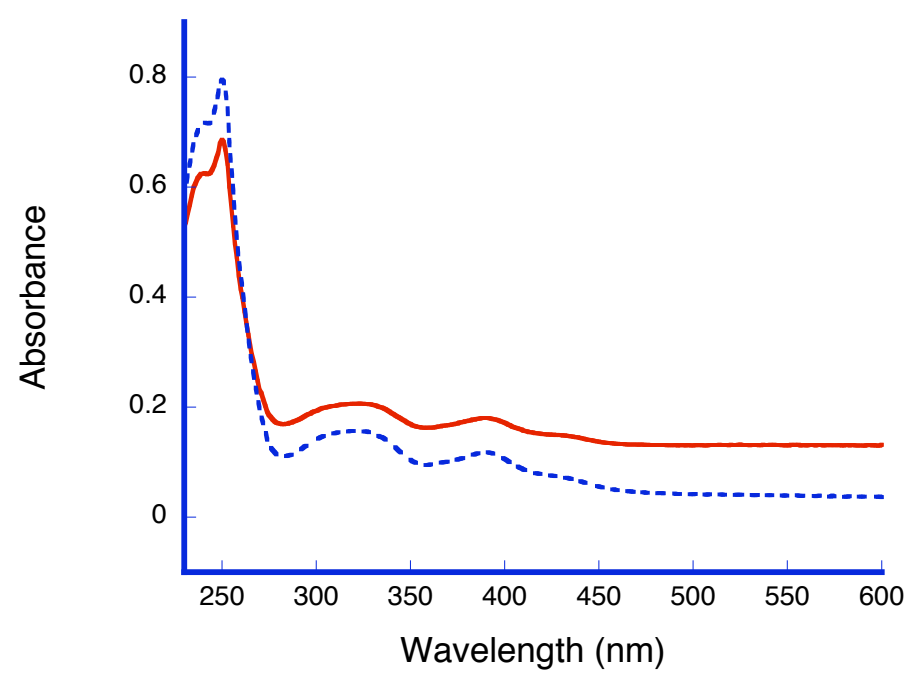

Figure S5: Electronic absorption spectra of processed (---) and unprocessed (-) $\mathrm{Ni}^{\mathrm{II}}$ (salen) suspended in phosphate buffer solution $(0.05 \mathrm{M}, \mathrm{pH}=7.2)$

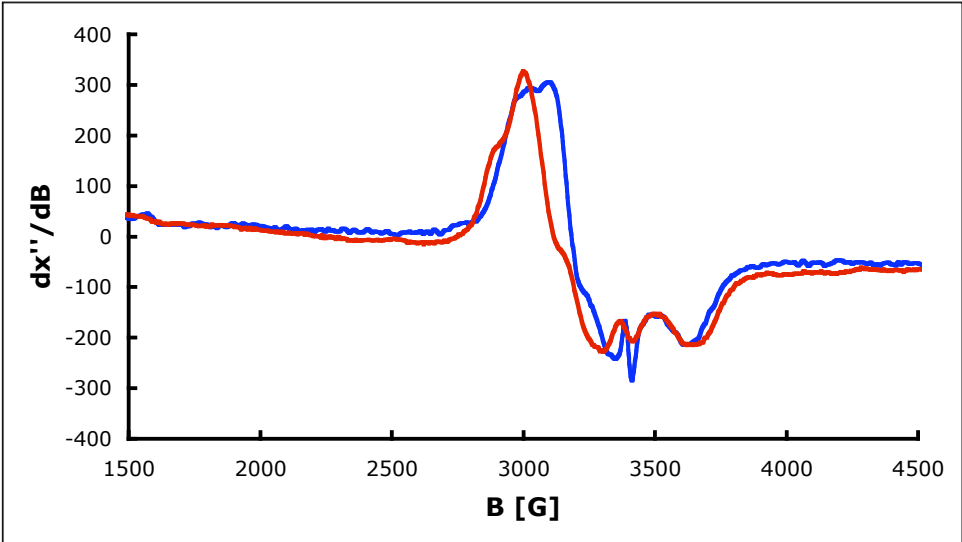

Figure S6: X-band EPR spectra measured at $77 \mathrm{~K}$ for solid samples of processed (red line) and unprocessed (blue line) $\mathrm{Ru}($ salen $)(\mathrm{NO})(\mathrm{Cl})$ 


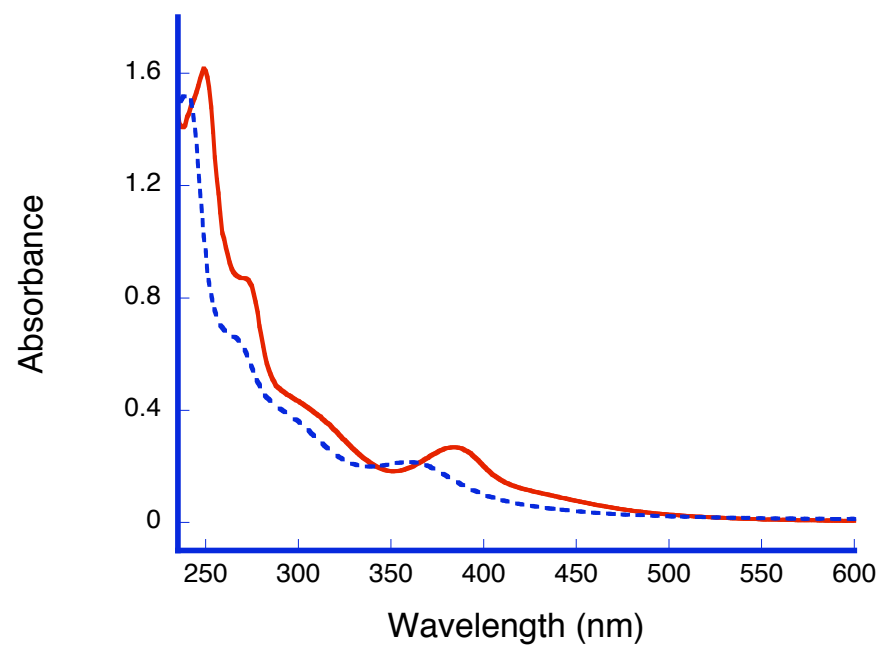

Figure S7: Electronic absorption spectra of processed (---) and unprocessed (-) $\mathrm{Ru}($ salen $)(\mathrm{NO})(\mathrm{Cl})$ suspended in phosphate buffer solution $(0.05 \mathrm{M}, \mathrm{pH}=7.2)$

\section{Physical Methods}

NMR spectra were recorded on Bruker DRX400 $400 \mathrm{MHz}$ spectrometers equipped with Silicon Graphics workstations. Electronic absorbance spectra were recorded with a Cary 50 spectrophotometer using a $1.00 \mathrm{~cm}$ quartz cuvet. FTIR spectra were collected on a Mattson Genesis series FTIR instrument with values reported in wavenumbers. EPR spectra were collected using a Bruker EMX spectrometer equipped with an ER4102ST cavity.

\section{References}

${ }^{1}$ Freire, C.; De Castro, B. J. Chem. Soc. Dalton Trans. 1998, 1491.

${ }^{2}$ Garg, B.S.; Deo Nandan, K. Spectrochimica Acta Part A. 2003, 59, 229.

${ }^{3}$ Koch-Mitchell, J. PhD Dissertation. 2003, University of Kansas, Lawrence KS, USA.

${ }^{4}$ Works C.F.; Jocher, C.J.; Bart, G.D.; Bu, X.; Ford, P. Inorg. Chem. 2002, 41, 3728.

${ }^{5}$ Jacobsen, E.N; Zhang, W.; Muci, A.R.; Ecker, J.R.; Deng, L. J. Am. Chem. Soc. 1991, $113,7063-7064$ and supporting information.

${ }^{6}$ Larrow, J.F.; Jacobsen, E.N. J. Org. Chem. 1994, 59, 1939 - 1942.

${ }^{7}$ Johnson, C.A. Master's Thesis. 2004, University of Kansas, Lawrence KS, USA.

${ }^{8}$ Fusaro, F.; Hänchen, M.; Mazzotti, M.; Muhrer, G.; Subramaniam, B. Ind. Eng. Chem. Res. 2005, 44, 1502-1509. 